\title{
Charakterystyka pojemności wymiany kationowej CEC skał ilastych o różnym stopniu diagenezy
}

\begin{abstract}
Celem pracy jest charakterystyka skał ilastych fliszu karpackiego pod względem zdolności do pęcznienia, wykonana na podstawie analizy własności fizykochemicznych (CEC) i analizy mineralogicznej. Przebadano skały fliszowe reprezentujące całe spektrum stopnia illityzacji: od 10 do 94\% pakietów smektytowych w minerale mieszanopakietowym illit-smektyt. Dysponowanie tak szeroką bazą danych umożliwiło kompleksową charakterystykę badanych skał oraz powiązanie zdolności jonowymiennych z ilością i rodzajem materiału ilastego.
\end{abstract}

Słowa kluczowe: pojemność wymiany kationowej, pęcznienie iłów, minerał mieszanopakietowy illit-smektyt.

\section{Characterization of the cation exchange capacity of clay rocks of varying degrees of diagenesis}

The aim of the presented work was the characterization of the Carpathian Flysch rocks swelling capacity based on the analysis of their physicochemical (CEC) and mineralogical properties. Flysch sediments representing the whole range of illitization: from $10 \%$ to $94 \%$ of smectite layers in the mixed layered mineral illite-smectite were investigated. Such a broad database enabled comprehensive characterization of the investigated rocks swelling properties and relating the cation exchange capacity to the amount and type of clay minerals.

Key words: cation exchange capacity, swelling of clays, the mixed layered mineral illite-smectite.

\section{Wstęp}

Pojemność wymiany kationowej jest bardzo istotnym parametrem wykorzystywanym w badaniach skał osadowych. Pozwala na określenie zdolności skał do pęcznienia, wytrzymałości mechanicznej, zdolności sorbcyjnych, ułatwia przewidywanie możliwości reakcji przewiercanych skał z płuczką wiertniczą i prognozowanie uszkodzeń strefy przyodwiertowej. Parametr ten jest wskaźnikiem własności elektrycznych skał i znajduje zastosowanie w modelach wykorzystywanych do oceny nasycenia wodą na podstawie profilowań geofizycznych, takich jak model Waxmana-Smitha i Dual-Water. Zdolność wymiany kationowej skał jest ściśle związana z rodzajem i ilością minerałów ilastych charakteryzujących się dużą powierzchnią właściwą. Na wartość parametru CEC wpływają sumaryczna zawartość iłów oraz ich zdolności do pęcznienia, określone w większości skał silikoklastycznych przez zawartość pakietów smektytowych w minerale mieszanopakietowym illit-smektyt [6,9].

Celem pracy była charakterystyka skał ilastych fliszu karpackiego pod względem ich zdolności do pęcznienia, wykonana na podstawie kompleksowej analizy porównawczej własności fizykochemicznych (CEC) i analizy mineralogicznej. Dysponowanie szeroką bazą danych (duża ilość próbek o zróżnicowanych wartościach CEC), obejmującą cały zakres pomiarowy, umożliwiło przeprowadzenie badań metodycznych pod kątem doboru stężenia roztworu wzorcowego w pomiarach pojemności wymiany kationowej.

\section{Metodyka}

W ramach przedstawionej pracy wykonano pomiary pojemności wymiany kationowej CEC oraz ilościowego składu mineralnego skał ilastych o zróżnicowanych zdolnościach jonowymiennych, zawierających minerał mieszanopakietowy 
illit-smektyt o zawartości pakietów smektytowych od 10 do 90\%. Przeprowadzone badania stanowią uzupełnienie wcześniej wykonanych analiz dla mocno zdiagenezowanych skał, reprezentujących formacje łupków gazonośnych i słabo zmienionych skał mioceńskich [6].

Skład mineralny skał został określony na podstawie ilościowej analizy rentgenowskiej wykonywanej standardowo w Zakładzie Geofizyki Wiertniczej INiG - PIB w Krakowie [4]. Skład frakcji ilastej uzyskano poprzez analizę rentgenowską wydzielonej frakcji $<0,2 \mu \mathrm{m}$. Charakterystykę minerału mieszanopakietowego illit-smektyt (określenie zawartości pakietów smektytowych - \% S) przeprowadzono przy pomocy metodyki Środonia $[8,10,11]$.

Pomiary pojemności wymiany kationowej CEC wykonano metodą heksaaminy kobaltowej $[1,3,5,13]$, która polega na badaniu zmiany stężenia kationu wskaźnikowego $\mathrm{Co}\left[\mathrm{NH}_{3}\right]_{6}{ }^{+++}$przed i po wprowadzeniu roztworu do próbki. Stężenie roztworu określane jest metodą spektrofotometryczną. Wykorzystuje się zależność pomiędzy absorbancją a stężeniem kationu wskaźnikowego. Stężenie wzorcowego roztworu heksaaminy kobaltowej dobierane jest w zależności od przewidywanej wartości CEC, przy czym maksymalnie może ono wynieść $0,01495 \mathrm{~mol} / 1$, ponieważ przy wyższej koncentracji roztworu zależność pomiędzy absorbancją a stężeniem traci liniowy charakter [1]. Dobór stężenia roztworu wzorcowego jest bardzo istotny dla uzyskania poprawnych wartości pojemności wymiany kationowej. Im większa wartość CEC, tym wyższe powinno być stężenie roztworu wzorcowego. Jeśli dla próbki o dużej zdolności jonowymiennej użyty zostanie roztwór o zbyt niskim stężeniu lub za mała jego ilość, reakcja nie zajdzie do końca, nie wszystkie kationy zostaną wymienione przez kation wskaźnikowy. Odwrotna sytuacja zaistnieje, jeżeli użyjemy roztworu o zbyt wysokim stężeniu lub jego za dużą ilość w stosunku do wartości CEC próbki. Zmiana stężenia roztworu, a więc także mierzonego zabarwienia, będzie wtedy zbyt mała dla uzyskania dokładnego wyniku. W obu przypadkach otrzymamy zaniżone wartości CEC [5]. Wstępne badania mające na celu dobór stężenia roztworu wzorcowego właściwego dla badanych próbek przy zastosowaniu roztworów o różnych stężeniach molowych wykazały, że roztwór o najniższym

Tablica 1. Roztwory wzorcowe heksaaminy kobaltowej stosowane dla próbek o różnym zakresie wartości CEC

\begin{tabular}{|c|c|c|}
\hline $\begin{array}{c}\text { Roztwór } \\
\text { wzorcowy }\end{array}$ & $\begin{array}{c}\text { Stężenie molowe } \\
{[\mathrm{mol} / \mathrm{l}]}\end{array}$ & $\begin{array}{c}\text { Zakres wartości CEC } \\
{[\mathrm{mval} / 100 \mathrm{~g}]}\end{array}$ \\
\hline I & 0,00150 & - \\
\hline II & 0,00374 & $<12$ \\
\hline III & 0,00748 & $10 \div 30$ \\
\hline IV & 0,01495 & $>30$ \\
\hline
\end{tabular}

stężeniu daje w każdym wypadku zaniżone wartości. Wyniki uzyskane dla roztworów II i III są zbliżone, a roztwór o najwyższym stężeniu dostarcza zaniżonych wyników dla próbek o wartości CEC poniżej 20 mval/100 g [5].

W celu dopracowania metodyki badań CEC dla całego zakresu pomiarowego, przeprowadzono badania porównawcze dla dużej ilości próbek o zróżnicowanych wartościach CEC, a w szczególności uzupełniono bazę danych o pomiary na próbkach o wysokiej zdolności jonowymiennej. Zestawiono wyniki pomiarów pojemności wymiany kationowej uzyskane dla roztworów wzorcowych II i III, dla 47 próbek o wartości CEC od około 4,5 mval/100 g do $20 \mathrm{mval} / 100 \mathrm{~g}$ (rysunek 1). Analiza otrzymanych wyników pozwoliła na wydzielenie trzech odmiennie reagujących z roztworami wzorcowymi grup próbek:

I. próbki o wartości CEC poniżej $10 \mathrm{mval} / 100 \mathrm{~g}$,

II. próbki o wartości CEC od $10 \mathrm{mval} / 100 \mathrm{~g}$ do $12 \mathrm{mval} / 100 \mathrm{~g}$, III. próbki o wartości CEC powyżej $12 \mathrm{mval} / 100 \mathrm{~g}$.

W przypadku próbek z grupy I lepsze wyniki uzyskano dla wzorca II, zaniżone wartości otrzymane dla pomiarów z użyciem wzorca III świadczą o zbyt wysokim stężeniu tego roztworu. Z kolei dla próbek z grupy III zdecydowanie wyższe wartości CEC uzyskano dla roztworu wzorcowego III. Próbki z grupy II reagują w podobny sposób z roztworem wzorcowym II, jak i III. Stwierdzono zatem, że dla próbek o wartości CEC poniżej 10 mval/100 g należy stosować roztwór wzorcowy II, a dla próbek o wartości CEC powyżej $12 \mathrm{mval} / 100 \mathrm{~g}$ - wzorzec III (tablica 1). Próbki z przedziału wartości CEC $10 \div 12 \mathrm{mval} / 100 \mathrm{~g}$ mogą być mierzone zarówno przy pomocy roztworu wzorcowego II, jak i III. W praktyce oznacza to, że wzorzec II stosujemy dla skał węglanowych, słabo zailonych piaskowców oraz mocno zdiagenezowanych skał ilastych, takich jak np. łupki dolnopaleozoiczne. Wzorzec III używamy dla mniej zdiagenezownych, zailonych piaskowców i skał ilastych, np. osadów fliszu karpackiego i miocenu. W przypadkach wątpliwych należy wykonać pomiary dla dwóch wzorców.

Uzupełnienie bazy danych o wyniki pomiarów próbek o wartości CEC powyżej 20 mval/100 g (rysunek 2), w tym próbek czystych smektytów (próbki referencyjne opisane poniżej) o wartości CEC powyżej 70 mval/100 g, pozwoliło na sprawdzenie możliwości zastosowania wzorca o najwyższym stężeniu molowym (wzorzec IV). Dla próbek o wartości CEC poniżej $30 \mathrm{mval} / 100 \mathrm{~g}$ nie zaobserwowano żadnego trendu zmienności. Bardzo wyraźnie widać natomiast różnicę wyników pomiarów dla poszczególnych roztworów wzorcowych w przypadku próbek o bardzo wysokiej (powyżej 70 mval/100 g) pojemności wymiany kationowej; wartości uzyskane dla roztworu IV są tutaj zdecydowanie wyższe (rysunek 2). Zasadne jest zatem wykorzystanie roztworu wzorcowego o najwyższym stężeniu (tablica 1) w przypadku 


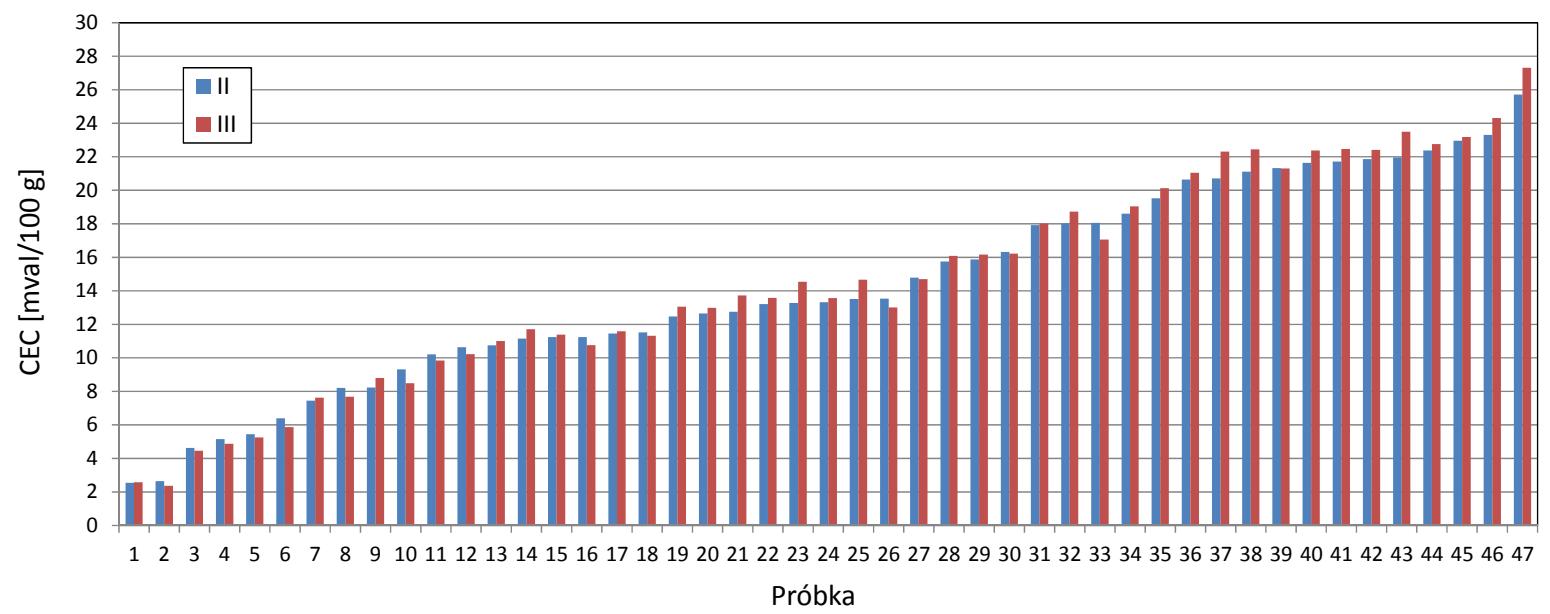

Rys. 1. Zmienność wartości pojemności wymiany kationowej CEC dla poszczególnych próbek w zależności od stężenia roztworu wzorcowego: II $-c_{m}=0,00374 \mathrm{~mol} / 1, \mathrm{III}-c_{m}=0,00748 \mathrm{~mol} / 1$

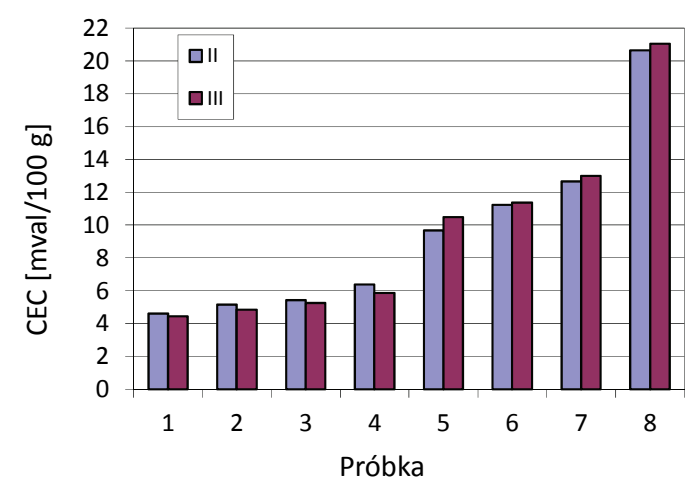

Rys. 2. Zmienność wartości pojemności wymiany kationowej

CEC dla poszczególnych próbek w zależności od stężenia roztworu wzorcowego: III $-c_{m}=0,00748 \mathrm{~mol} / 1$,

$$
\mathrm{IV}-c_{m}=0,01495 \mathrm{~mol} / 1
$$

monomineralnych próbek smektytowych o bardzo wysokich zdolnościach jonowymiennych. Wzorzec ten nie znajduje natomiast zastosowania dla większości badanych próbek skał (bardzo rzadko zdarza się, żeby wartość CEC przekroczyła 30 mval/100 g).

Tablica 2. Wyniki pomiarów pojemności wymiany kationowej CEC dla minerałów source clays

\begin{tabular}{|l|c|c|c|}
\hline \multicolumn{1}{|c|}{ Minerał } & $\begin{array}{c}\mathrm{CEC}_{\mathrm{SCl}} \\
{\left[\mathrm{mval}_{100 \mathrm{~g}}\right]}\end{array}$ & $\begin{array}{c}\mathrm{CEC}_{\mathrm{lit}} \\
{[\mathrm{mval} / 100 \mathrm{~g}]}\end{array}$ & $\begin{array}{c}\mathrm{CEC}_{\text {INiG }} \\
{[\mathrm{mval} / 100 \mathrm{~g}]}\end{array}$ \\
\hline Ca-Montmoryllonit STx-1 & 84,4 & 76,1 & 76,82 \\
\hline Hektoryt (smektyt trioktaedryczny) SHCa-1 & 43,9 & - & 43,93 \\
\hline Na-montmoryllonit SWy-2 & 76,4 & 93,3 & 75,04 \\
\hline Kaolinit KGa-2 & 3,3 & - & 2,65 \\
\hline
\end{tabular}

Objaśnienia: $\mathrm{CEC}_{\mathrm{SCl}}$ - wartość $\mathrm{CEC}$ podana w bazie danych source clays, $\mathrm{CEC}_{\mathrm{lit}}$ - wartość $\mathrm{CEC}$ z danych literaturowych [3], $\mathrm{CEC}_{\mathrm{INGG}}-$ pomierzona wartość $\mathrm{CEC}$.
W celu potwierdzenia poprawności stosowanej metodyki wykonano pomiary na próbkach wzorcowych o podanej wartości CEC. Wzorce minerałów ilastych pochodzą z zasobów Clay Minerals Society, z repozytorium minerałów ilastych utworzonego (w ramach programu source clay minerale) w odpowiedzi na zapotrzebowanie na homogeniczne próbki iłów. Source clays są to minerały pochodzące z dużych, dobrze udokumentowanych próbek źródłowych (1 tona), dobranych tak, aby zminimalizować zmienność, a następnie poddanych homogenizacji. Taki sposób doboru prób gwarantuje porównywalność otrzymywanych wyników.

Wykonano pomiary pojemności wymiany kationowej dla czterech próbek o różnych wartościach pojemności wymiany kationowej (tablica 2), reprezentowanych przez trzy próbki smektytów i jedną próbkę kaolinitu. Przy doborze roztworów wzorcowych kierowano się wynikami wcześniejszych badań (rysunek 1,2). Dla próbek smektytowych zastosowano roztwór IV, a dla kaolinitu roztwór II.

Wartości CEC, uzyskane w Laboratorium Geofizyki Wiertniczej, są zgodne z wartościami referencyjnymi podanymi dla poszczególnych wzorców $[2,12]$. W przypadku próbek 2 i 3 jest to zgodność w granicach $1,5 \%$, dla próbek 1 i 4 wartości te są nieco niższe niż dane referencyjne.

\section{Materiał badawczy}

Badane próbki skał fliszowych reprezentowane są przez iłowce i mułowce zawierające, w większości przypadków, od
10 do $20 \%$ kwarcu i od 37 do $70 \%$ minerałów ilastych. Charakteryzują się one zmienną zawartością węglanów: od skał 
całkowicie ich pozbawionych po próbki zawierające ponad 30\% tych minerałów. W skład frakcji ilastej wchodzą miki i minerały z grupy illitu, minerały mieszanopakietowe illit-smektyt, chloryt i - niekiedy - kaolinit. Minerały mieszanopakietowe reprezentują całe spektrum stopnia illityzacji: zawierają od 10 do 94\% pakietów smektytowych (rysunek 3). Wartości pojemności wymiany kationowej CEC większości badanych skał mieszczą się w przedziale od 9 do $25 \mathrm{mval} / 100 \mathrm{~g}$.
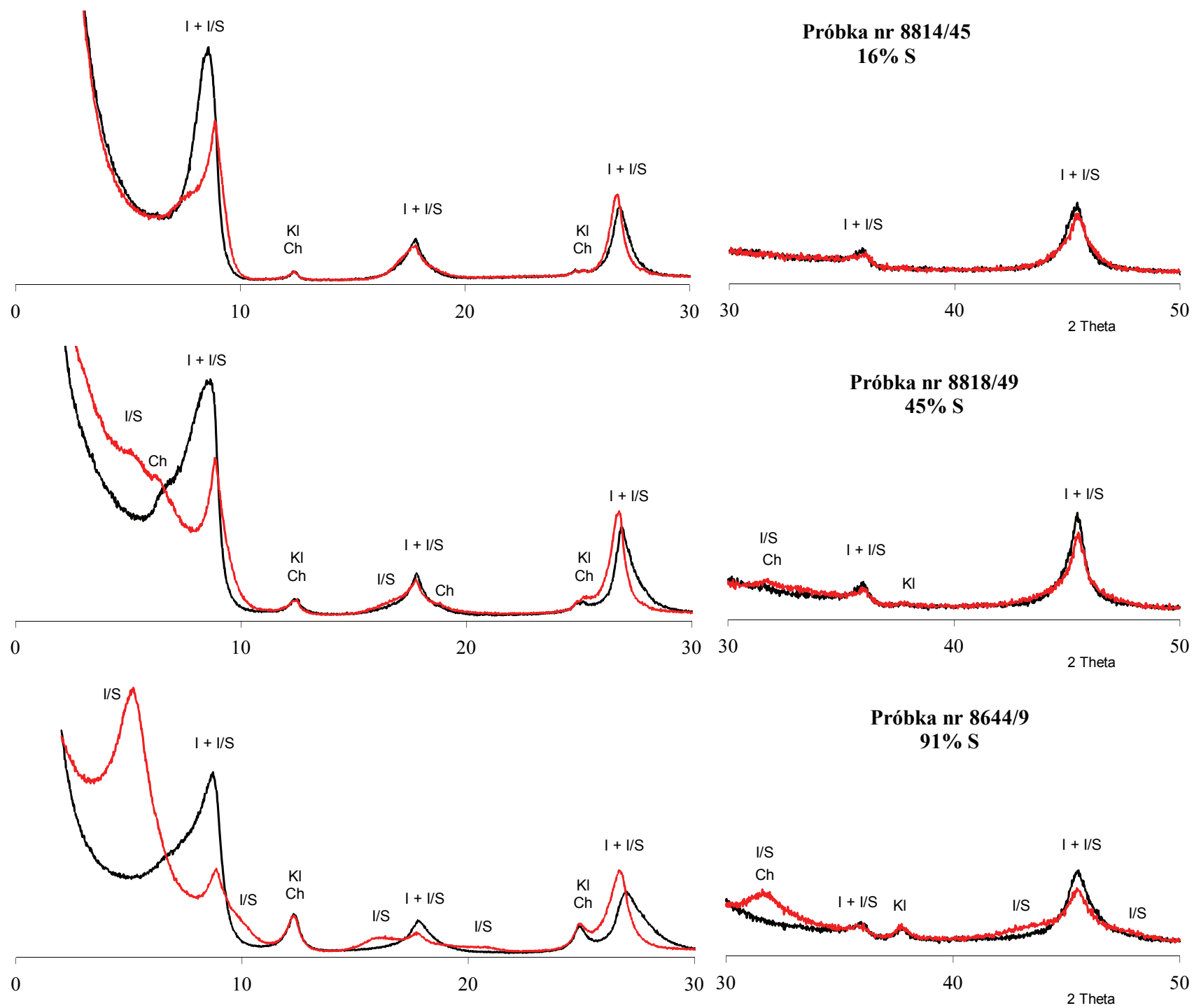

Rys. 3. Przykładowe dyfraktogramy rentgenowskie frakcji $<0,2 \mu \mathrm{m}$ badanych skał zawierających minerał mieszanopakietowy illit-smektyt o zróżnicowanej ilości pakietów smektytowych; czarna linia - preparat w stanie powietrznosuchym, czerwona linia - preparat glikolowany, I/S - minerał mieszanopakietowy illit-smektyt, I - illit, Ch - chloryt, Kl - kaolinit

\section{Wyniki}

Biorąc pod uwagę fakt, że zmienność wartości pojemności wymiany kationowej CEC związana jest $\mathrm{z}$ ilością $\mathrm{i}$ charakterem materiału ilastego, przeanalizowano związki pomiędzy wielkością CEC a sumaryczną zawartością minerałów ilastych w skale i zawartością pakietów smektytowych w minerale mieszanopakietowym illit-smektyt. Wartość CEC rośnie wraz ze wzrastającą ilością sumy minerałów ilastych (rysunek 4). Zależność ta jest szczególnie wyraźna dla grupy skał zawierających illit-smektyt o wysokiej zawartości pakietów smektytowych (>60\%) (rysunek $5 b$ ).
Widoczna jest zależność pomiędzy zdolnością jonowymienną badanych próbek a zawartością pakietów smektytowych w minerale mieszanopakietowym illit-smektyt (rysunek 6). Dwie odbiegające od ogólnego trendu próbki (8613/3 i 8642/7) charakteryzują się stosunkowo niską wartością CEC przy wysokiej zawartości pakietów smektytowych (rysunek 6). Jest to związane z niską sumaryczną ilością iłów.

W celu określenia związku pomiędzy wartością CEC a wszystkimi parametrami charakteryzującymi materiał ilasty zastosowano metodę regresji wielokrotnej. Otrzymano 


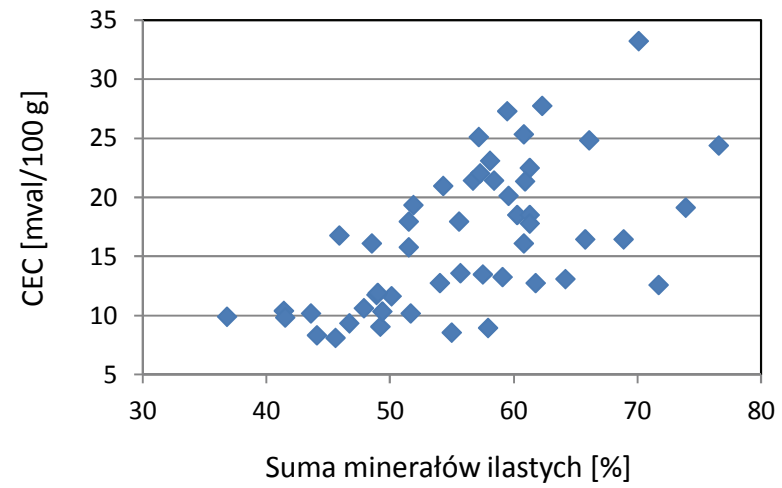

Rys. 4. Zależność pomiędzy wartością CEC a sumą minerałów ilastych dla wszystkich badanych skał
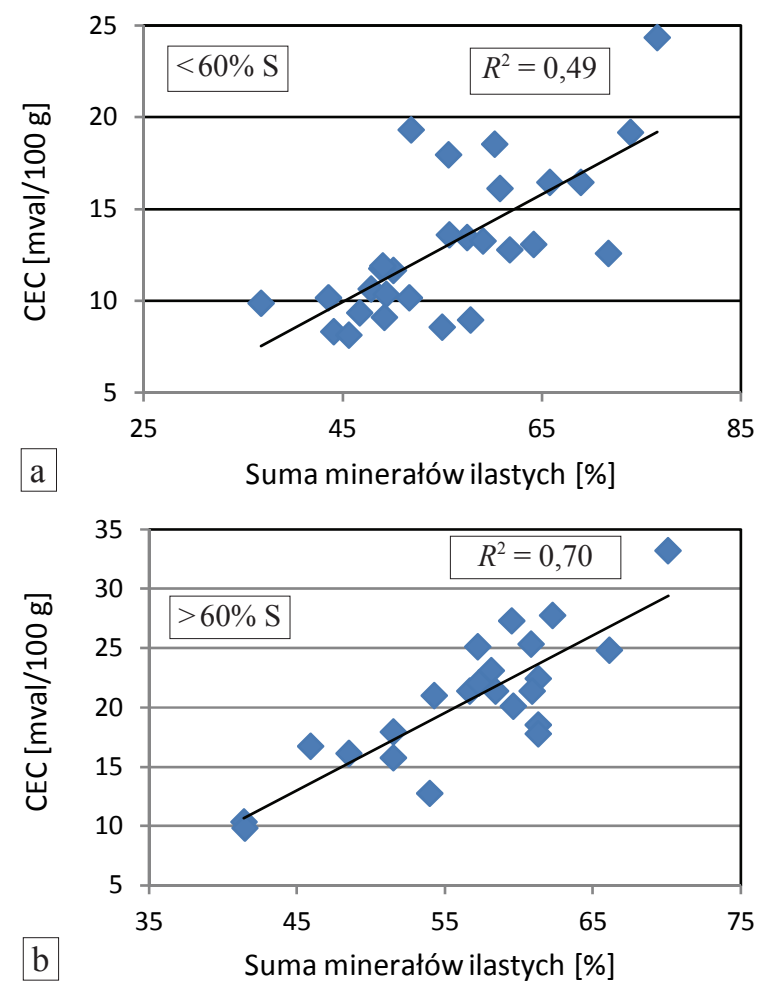

Rys. 5. Zależność pomiędzy wartością CEC a sumą minerałów ilastych dla wszystkich badanych skał, dla próbek zawierających illit-smektyt o ilości pakietów smektytowych niższej (a) i wyższej (b) niż 60\%

dobrą korelację pomiędzy wartością parametru CEC a sumą minerałów ilastych oraz zawartością pakietów smektytowych w minerale mieszanopakietowym illit-smektyt (rysunek 7).

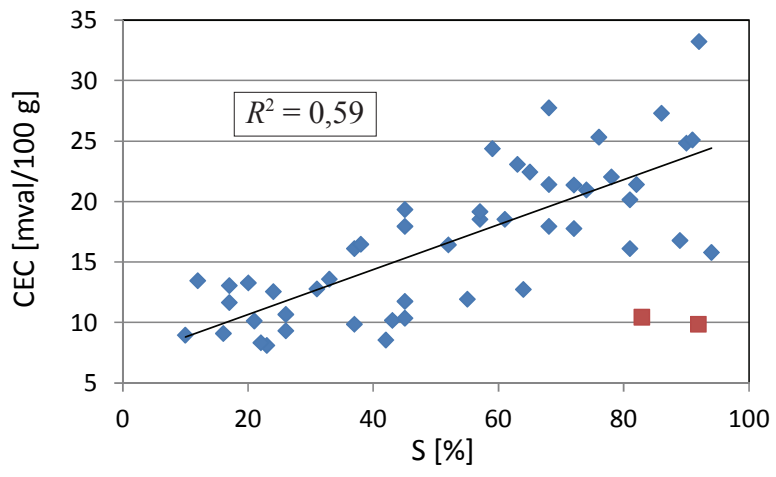

Rys. 6. Zależność pomiędzy zawartością pakietów smektytowych (\% S) a wartością CEC dla wszystkich badanych skał. Dwie próbki o najniższej ilości minerałów ilastych zaznaczono kolorem czerwonym

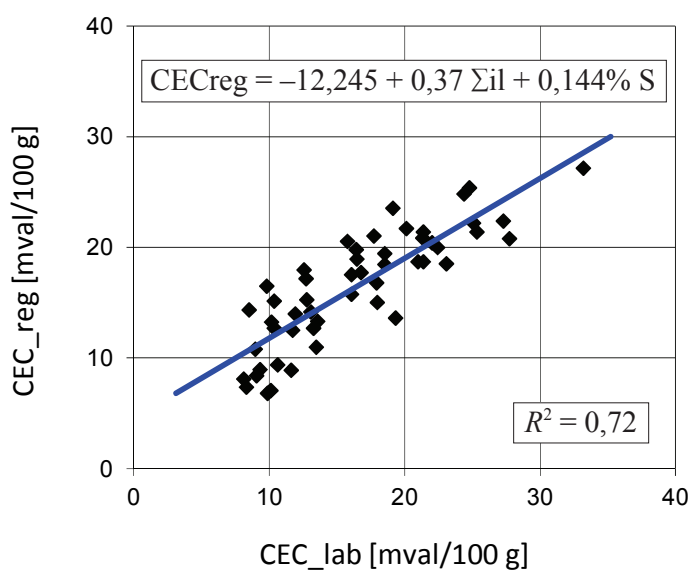

Rys. 7. Korelacja wartości parametru CEC uzyskanych dzięki badaniom laboratoryjnym (CEC lab) i modelom matematycznym (CEC_reg) przy uwzględnieniu dwóch parametrów: suma minerałów ilastych i zawartość pakietów smektytowych (\% S) w minerale illit-smektyt

W obrębie badanych skał fliszu karpackiego wyróżniono, na podstawie wartości pojemności wymiany kationowej CEC (według klasyfikacji Stephens et al., 2009 [7]), grupy skał o różnych zdolnościach do pęcznienia. Analiza badanych parametrów pozwoliła na charakterystykę materiału ilastego w poszczególnych grupach (tablica 3 ).

Najwięcej próbek należy do grupy o pośredniej reaktywności (wartości CEC od 10 do $20 \mathrm{mval} / 100 \mathrm{~g}$ ). Skały te odznaczają się dużą zmiennością wartości parametrów charakteryzujących materiał ilasty (tablica 3, rysunek 8). Dość liczna

Tablica 3. Charakterystyka grup skał ilastych fliszu karpackiego o różnych zdolnościach do pęcznienia

\begin{tabular}{|c|l|c|c|c|}
\hline \multicolumn{2}{|c|}{ Grupa } & $\begin{array}{c}\text { CEC } \\
{[\mathrm{mval} / 100 \mathrm{~g}]}\end{array}$ & $\begin{array}{c}\text { Sil } \\
{[\%]}\end{array}$ & $\begin{array}{c}\text { S } \\
{[\%]}\end{array}$ \\
\hline I & Skały nie wykazujące zdolności do pęcznienia & $<10$ & $<50$ & $<30$ \\
\hline II & Skały o pośredniej reaktywności & $10 \div 20$ & cały zakres zmienności & $>20$ \\
\hline III & Skały wykazujące duże zdolności do pęcznienia & $>20$ & $>55$ & $>60$ \\
\hline
\end{tabular}

Objaśnienia: il - suma minerałów ilastych; \% S - zawartość pakietów smektytowych w minerale mieszanopakietowym illit-smektyt 


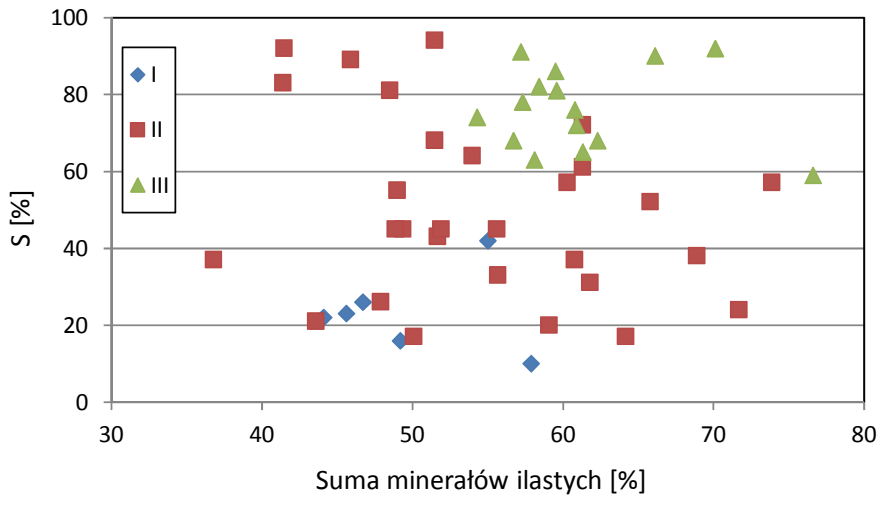

Rys. 8. Grupy skał ilastych fliszu karpackiego o różnych zdolnościach do pęcznienia; I - skały o niskiej zdolności do pęcznienia (CEC $<10 \mathrm{mval} / 100 \mathrm{~g}$ ), II - skały o pośredniej reaktywności (CEC 10 $\div 20 \mathrm{mval} / 100 \mathrm{~g}$ ), III - skały wykazujące duże zdolności do pęcznienia (CEC>20 mval/100 g)

(15 próbek) jest również grupa skał o dużych zdolnościach do pęcznienia (CEC > $20 \mathrm{mval} / 100 \mathrm{~g}$ ), charakteryzująca się, w większości przypadków, ilością minerałów ilastych przekraczającą 50\% i zawartością pakietów smektytowych (\% S) powyżej 60\% (tablica 3, rysunek 8). Najmniej próbek (6) należy do grupy skał niewykazujących zdolności do pęcznienia, zawierają one najczęściej poniżej 50\% minerałów ilastych i poniżej 30\% pakietów smektytowych w minerale mieszanopakietowym illit-smektyt (tablica 3, rysunek 8).

Parametry charakteryzujące wyróżnione grupy skał fliszowych porównano z właściwościami przebadanych wcześniej [6] próbek reprezentujących inne formacje skalne: mocno zdiagenezowanych dolnopaleozoicznych łupków gazo- nośnych i słabo zmienionych skał mioceńskich (rysunek 9). Analiza zestawionych danych wykazała, że dla skał o średniej i wysokiej reaktywności (grupy II i III) zakresy parametrów charakteryzujących materiał ilasty (suma minerałów ilastych i zawartość pakietów smektytowych w minerale illit-smektyt) nie ulegają zmianie. Z inną sytuacją mamy do czynienia w przypadku skał niewykazujących zdolności do pęcznienia (grupa I). Dominują tutaj mocno zdiagenezowane skały dolnopalezoiczne charakteryzujące się zróżnicowaną zawartością minerałów ilastych (często powyżej $50 \%$ ), zawierające, w większości przypadków, poniżej $20 \%$ pakietów smektytowych w minerale mieszanopakietowym illit-smektyt (rysunek 9).

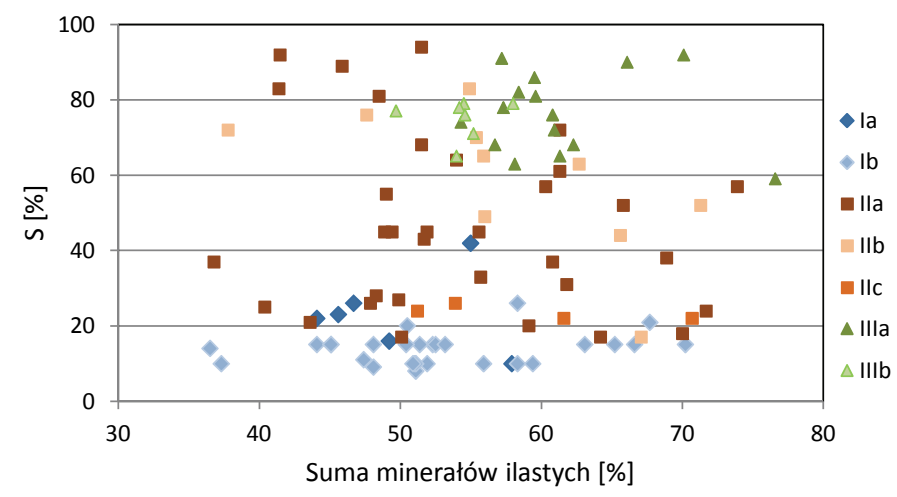

Rys. 9. Grupy skał ilastych o różnych zdolnościach do pęcznienia; I - skały o niskiej zdolności do pęcznienia (CEC $<10$ mval/100 g): a - flisz, b - dolny paleozoik; II - skały o pośredniej reaktywności (CEC 10 $\div 20 \mathrm{mval} / 100 \mathrm{~g})$ : a - flisz, b - miocen, c - dolny paleozoik; III - skały wykazujące duże zdolności do pęcznienia (CEC>20 mval/100 g): a - flisz, b - miocen

\section{Podsumowanie i wnioski}

Badania porównawcze wykonane dla dużej ilości próbek o zróżnicowanej wartości CEC, a w szczególności uzupełnienie bazy danych o pomiary na próbkach o wysokiej zdolności jonowymiennej, umożliwiły dopracowanie metodyki badań pod kątem doboru stężenia roztworu heksaaminy kobaltowej dla całego zakresu pomiarowego. Wyniki pomiarów pojemności wymiany kationowej wykonane z użyciem czterech próbek wzorcowych source clays wykazały dobrą zgodność z wartościami referencyjnymi, co potwierdza poprawność stosowanej w Laboratorium Geofizyki Wiertniczej metodyki pomiarowej.

Przebadane skały fliszu karpackiego charakteryzują się zróżnicowanymi wartościami wielkości pojemności wymiany kationowej: od skał o niskiej zdolności do pęcznienia $(\mathrm{CEC}<10 \mathrm{mval} / 100 \mathrm{~g})$, poprzez dużą grupę skał o średniej reaktywności, do utworów wykazujących duże zdolności do pęcznienia (CEC > $20 \mathrm{mval} / 100 \mathrm{~g})$. Reprezentują całe spektrum stopnia illityzacji: od praktyczne czystego illitu (10\% pakietów smektytowych $\mathrm{w}$ minerale mieszanopakietowym illit-smektyt) do smektytu (94\% pakietów smektytowych), charakteryzują się przy tym również zróżnicowaną zawartością sumy minerałów ilastych. Dysponowanie tak szeroką bazą danych umożliwiło kompleksową charakterystykę badanych skał - powiązanie zdolności jonowymiennych z ilością i rodzajem materiału ilastego.

Trzy grupy skał fliszowych o różnych zdolnościach do pęcznienia, wyróżnione na podstawie wartości parametru CEC, odznaczają się odmiennymi właściwościami materiału ilastego. Skały wykazujące duże zdolności do pęcznienia charakteryzują się zawartością co najmniej 50\% minerałów ilastych i $60 \%$ pakietów smektytowych w minerale mieszanopakietowym illit-smektyt, niewielka grupa skał niepęczniejących zawiera natomiast poniżej 50\% minerałów ilastych i mniej niż 30\% pakietów smektytowych w minerale illit-smektyt. 
Na podstawie analizy właściwości skał fliszowych, w połączeniu z utworami reprezentującymi inne formacje skalne: mocno zdiagenezowane dolnopaleozoiczne łupki gazonośne isłabo zmienione skały mioceńskie, stwierdzono, że w grupie I (skały niewykazujące zdolności pęczniejących) dominują mocno zdiagenezowane dolnopaleozoiczne łupki gazonośne, także charakteryzujące się wysoką (powyżej 50\%) zawartością minerałów ilastych. Skały fliszowe należą zarówno do grupy II (skały o średniej reaktywności), jak i III (skały wykazujące duże zdolności do pęcznienia), tylko kilka próbek wchodzi w skład grupy I. Najmniej zmienione utwory mioceńskie występują tylko w grupach II i III.

Pojemność wymiany kationowej powiększa się wraz z rosnącymi wartościami sumy minerałów ilastych oraz ilości pakietów smektytowych $(\% \mathrm{~S})$ w minerale illit-smektyt. Najlepszą korelację $\left(R^{2}=0,72\right)$ uzyskano, biorąc pod uwage jednoczesny wpływ obu parametrów. Otrzymana zależność może posłużyć do szacowania wartości CEC na podstawie parametrów cechujących materiał ilasty w skałach fliszu karpackiego.

Podsumowując powyższe rozważania, należy stwierdzić, że parametr pojemności wymiany kationowej CEC, w połączeniu z analizą minerałów ilastych, może być wykorzystywany do określania własności pęcznienia różnego rodzaju skał ilastych w profilu otworu, co ma szczególnie duże znaczenie w przypadku badania wpływu płuczki wiertniczej na przewiercane skały, czy też ocenę uszkodzenia strefy przyodwiertowej. Ze względu na niewielką ilość potrzebnej próbki i stosunkowo krótki czas pomiaru, parametr CEC umożliwia szybką ocenę zmienności zdolności do pęcznienia skał ilastych w profilu otworu i wyróżnienie interwałów o wysokiej reaktywności.

\section{Prosimy cytować jako: Nafta-Gaz 2016, nr 7, s. 513-519, DOI: 10.18668/NG.2016.07.03}

Artykuł nadesłano do Redakcji 22.12.2015 r. Zatwierdzono do druku 16.03.2016 r.

Artykuł powstał na podstawie pracy statutowej pt. Paleotermometr illitowo-smektytowy jako narzędzie analizy lokalnych elementów jednostek tektonicznych - praca INiG - PIB na zlecenie MNiSW; nr zlecenia: 62/SW/15, nr archiwalny: DK-4100-62/15.

\section{Literatura}

[1] Bardon Ch.: Recommendations pour la déterrmination experimentale de la capacité d'échange de cations des milieu argileux. Revue de l'Institut Français du Pétrole 1983, vol. 38, nr 5, s. 621-626.

[2] Clay Minerals Society - Source Clays, 2015; http://www.clays. org/SOURCE\%20CLAYS/SCdata.html (dostęp: grudzień 2015).

[3] Derkowski A., Bristow T. F.: On the problems of total specific surface area and cation exchange capacity measurements in organic-rich sedimentary rocks. Clays and Clay Minerals 2012, vol. 60, nr 4, s. 348-362.

[4] Kowalska S.: Określenie ilościowego składu mineralnego skat zawierajacych mineraty ilaste metoda Rietvelda. Nafta-Gaz 2013, nr 12, s. 894-902.

[5] Przelaskowska A., Klaja J.: Pomiary pojemności wymiany kationowej skat CEC w badaniach skat osadowych. NaftaGaz 2014, nr 7, s. 432-438.

[6] Przelaskowska A., Łykowska G., Klaja J., Kowalska S., Gąsior I.: Wykorzystanie parametru pojemności wymiany kationowej CEC do charakterystyki zdolności pęcznienia skat ilastych dolnego paleozoiku, fliszu karpackiego i miocenu zapadliska przedkarpackiego. Nafta-Gaz 2015, nr 6, s. 384-389.

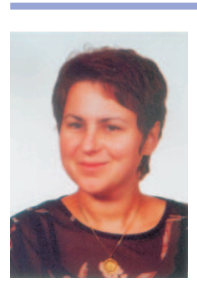

Mgr Anna PRZELASKOWSKA

Starszy specjalista badawczo-techniczny

w Zakładzie Geofizyki Wiertniczej.

Instytut Nafty i Gazu - Państwowy Instytut Badawczy

ul. Lubicz 25 A

31-503 Kraków

E-mail: anna.przelaskowska@inig.pl
[7] Stephens M., Gomez-Nava S., Churan M.: Laboratory methods to assess shale reactivity with drilling fluids. American Association of Drilling Engineers. National Technical Conference \& Exhibition, New Orleans, Louisiana, 2009.

[8] Środoń J.: Precise identification of illite/smectite interstratification by X-ray powder diffraction. Clays and Clay Minerals 1980, vol. 28, s. 401-411.

[9] Środon J.: Quantification of illite and smectite and their layer charges in sandstones and shales from shallow burial depth. Clay Minerals 2009, vol. 44, s. 421-434.

[10] Środoń J.: X-ray identification of randomly interstratified illite/smectite in mixtures with discrete illite. Clay Minerals 1981, vol. 16, s. 297-304.

[11] Środon J.: X-ray powder diffraction identification of illitic materials. Clays and Clay Minerals 1984, vol. 32, s. 337-349.

[12] Van Olphen H., Fripiat J. J.: Data Handbook for Clay Materials and Other Non-Metallic Minerals. Clay Minerals Society, 1979.

\section{Akty prawne i normatywne}

[13] Norma AFNOR NFX31-130 Détermination de la capacité d'échange cationique (CEC) et des cations extractibles, 1999.

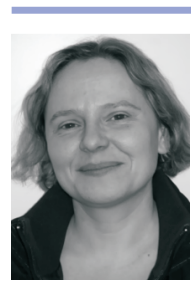

Dr Sylwia KOWALSKA

Adiunkt w Zakładzie Geofizyki Wiertniczej.

Instytut Nafty i Gazu - Państwowy Instytut Badawczy

ul. Lubicz 25 A

31-503 Kraków

E-mail: sylwia.kowalska@inig.pl 